\title{
A STUDY TO ASSESS THE EFFECT OF HEALTH TEACHING ON KNOWLEDGE REGARDING PREVENTION OF HYPOTHERMIA IN NEONATES AMONG MOTHERS OF NEONATES ADMITTED IN SELECTED HOSPITAL IN PUNE CITY.
}

\author{
Mr. KRISHNA NAND MITTAL \\ (PRINCIPAL) \\ D H COLLEGE OF NURSING, JAIPUR \\ Corresponding email: knmitta103@gmail.com
}

\begin{abstract}
Introduction The world health organization recognizes neonates' thermal care as a critical and essential component of essential newborn care; however, hypothermia continues to remain under-documented and under-managed. Material \& Methods: Quasi experimental one group pretest and post test research design was used. Sample comprise of 60 mothers of neonates admitted in bhosari hospital and jijamata hospital in pune city. Non-Probability Convenience sampling technique was used. The structured interview schedule was used in this study. Result: The scores obtained by the sample in the pre-test phase was mean knowledge score is 13.63 and in post phase was increased to 17.28.Conclusion: The health teaching on knowledge of prevention of hypothermia found to be effective in increasing the knowledge of mother. The samples had a highly significant gain in knowledge after the health teaching program.
\end{abstract}

Keyword: assess, knowledge, hypothermia, neonates, mothers.

\section{INTRODUCTION}

At birth, the neonate has to strike a balance between its capacities to generate heat, and the imminent processes of heat loss if it is to successfully transit from intrauterine to extra uterine life. However, even the initial delivery room resuscitation may impede with this balance, and heat loss overwhelms the limited capacity of the preterm infant for heat production. The urgency of the initial resuscitative procedures often takes precedence over the attention given to thermoregulation inevitably leading to hypothermia.

The World Health Organization (WHO) clearly defines normal newborn temperature to be between $36.5-37.5^{\circ} \mathrm{C}$
(97.7-99.5 $\left.{ }^{\circ} \mathrm{F}\right)$. Furthermore, it classifies that cold stress as occurring between 36.0$36.5^{\circ} \mathrm{C}$, moderate hypothermia at 32.0 $36.0^{\circ} \mathrm{C}$, and severe hypothermia at $<32^{\circ} \mathrm{C}$. The consequences of severe hypothermia are well known. It leads to a vicious cycle of severe hypoxia and acidosis that result in a failed adaptation to extrauterine life and death. It has been shown to be independently associated with death and predictive of oxygen dependency in infants $<26$-week of gestation. 


\section{OBJECTIVES OF THE STUDY}

1) To identify the existing knowledge related to prevention of hypothermia in neonates among mothers of neonates.

2) To determine the post test knowledge related to hypothermia in neonates among mothers of neonates after health teaching.

3) To find an association between level of knowledge of mothers of neonates with selected demographic variables

\section{RESEARCH METHODOLOGY}

RESEARCH APPORACH This study aimed at the developing and evaluating a teaching program. Hence, it was felt that an evaluative research approach enables the investigator to evaluate the effectiveness of this health teaching in terms of knowledge gain.

RESEARCH DESIGN In the present study the investigator selected single group pre test-post test design.

VARIABLES: In this study Independent variables the health teaching on Prevention of hypothermia in neonate. In this study Dependent variable in the study is knowledge score among the mothers.

SETTING OF THE STUDY The study was conducted in bhosari hospital and Jijamata hospital in pune city.

SAMPLE AND SAMPLING

\section{TECHNIQUE}

Non-Probability Convenience sampling technique.

SAMPLE SIZE Sample comprise of 60 mothers of neonates admitted in bhosari hospital and jijamata hospital in pune city. The sample size was 60 .

\section{DATA COLLECTION TECHNIQUE} structured interview schedule techniques

\section{TOOLS \& TECHNIQUE}

Structured interview schedule

\section{DESCRIPTION OF THE TOOL}

\section{Structured interview schedule}

The structured interview schedule questionnaire consisted of two sections.

Section I Consisted of 6 items on demographic data such as age, education, occupation, family, monthly income, family type, religion, etc.

Section II comprised of 20 items to assess the effect of health teaching on knowledge of mothers regarding prevention of hypothermia in neonates.

In Section-II- this section comprised of 20 knowledge items with a maximum score of 20 categorized under two broad areas and one score was given for each correct response and zero for wrong response. The maximum score was 20 and minimum was zero. 


\section{SECTION I}

Analysis of data related to effect of health teaching on knowledge in study group.

Table 1:

Description of Category wise distribution of the knowledge scores.

$\mathrm{N}=60$

\begin{tabular}{|c|c|c|c|c|c|}
\hline $\begin{array}{l}\text { Sr. } \\
\text { No } \\
\text {. }\end{array}$ & Areas & $\begin{array}{l}\text { Pre-test } \\
\text { knowled } \\
\text { ge score }\end{array}$ & $\begin{array}{l}\text { Pre-test } \\
\text { frequenc } \\
y\end{array}$ & $\begin{array}{l}\text { Post-test } \\
\text { knowled } \\
\text { ge score }\end{array}$ & $\begin{array}{l}\text { Post-test } \\
\text { frequenc } \\
y\end{array}$ \\
\hline 1 & $\begin{array}{l}\text { Meaning of } \\
\text { Hypothermia }\end{array}$ & 118 & $65.5 \%$ & 151 & $83.89 \%$ \\
\hline 2 & $\begin{array}{l}\text { Causes of } \\
\text { Hypothermia }\end{array}$ & 107 & $89.16 \%$ & 114 & $95 \%$ \\
\hline 3 & $\begin{array}{l}\text { Sign- } \\
\text { Symptoms } \\
\text { Hypothermia }\end{array}$ & 72 & $60 \%$ & 92 & $76.67 \%$ \\
\hline 4 & $\begin{array}{l}\text { Management } \\
\text { of } \\
\text { Hypothermia }\end{array}$ & 336 & $70 \%$ & 409 & $85.20 \%$ \\
\hline 5 & $\begin{array}{l}\text { Complication } \\
\text { of } \\
\text { Hypothermia }\end{array}$ & 20 & $33.34 \%$ & 46 & $76.67 \%$ \\
\hline 6 & $\begin{array}{l}\text { Prevention of } \\
\text { Hypothermia }\end{array}$ & 161 & $67.08 \%$ & 208 & $86.67 \%$ \\
\hline
\end{tabular}

ANALYSIS OF DATA RELATED TO KNOWLEDGE OF MOTHER OF NEONATE BEFORE AND AFTER HEALTH TEACHING.
Table 2: DESCRIPTION OF CATEGORY WISE

DISTRIBUTION OF THE AVERAGE KNOWLEDGE SCORES

\begin{tabular}{|c|c|c|c|c|c|c|c|c|}
\hline \multirow{2}{*}{$\begin{array}{l} \\
\text { Sr } \\
\cdot \\
\text { N } \\
\text { o. }\end{array}$} & & & & & & & $=60$ & \\
\hline & \multirow[t]{2}{*}{ Areas } & \multicolumn{2}{|c|}{$\begin{array}{l}\text { Pre-test } \\
\text { knowledge } \\
\text { score }\end{array}$} & \multicolumn{2}{|c|}{$\begin{array}{l}\text { Post-test } \\
\text { knowledge } \\
\text { score }\end{array}$} & \multirow[t]{2}{*}{$\begin{array}{l}\text { paired } \\
\text { 't' } \\
\text { value }\end{array}$} & \multirow[t]{2}{*}{$\begin{array}{l}\text { Degree } \\
\text { of } \\
\text { freedom }\end{array}$} & \multirow[t]{2}{*}{$\begin{array}{l}\text { p' } \\
\text { value }\end{array}$} \\
\hline & & $\begin{array}{l}\text { Mean } \\
\text { Score }\end{array}$ & SD & $\begin{array}{l}\text { Mean } \\
\text { Score }\end{array}$ & SD & & & \\
\hline 1 & Meaning & 1.98 & .537 & 2.52 & .504 & -6.626 & 59 & .000 \\
\hline 2 & Causes & 1.78 & .415 & 1.90 & .303 & -2.791 & 59 & .000 \\
\hline 3 & $\begin{array}{l}\text { Sign and } \\
\text { symptoms }\end{array}$ & 1.20 & .684 & 1.53 & .566 & -4.106 & 59 & .000 \\
\hline 4 & Management & 5.62 & 1.075 & 6.82 & .748 & -7.460 & 59 & .000 \\
\hline 5 & Complication & .33 & .475 & .77 & .427 & -6.717 & 59 & .000 \\
\hline 6 & Prevention & 2.72 & .904 & 3.50 & .651 & -6.452 & 59 & .000 \\
\hline 7 & total & 13.73 & 1.593 & 17.28 & .976 & -15.97 & 59 & .000 \\
\hline
\end{tabular}

SECTION --III

ANALYSIS OF DATA RELATED TO EFFECT OF HEALTH TEACHING ON KNOWLEDGE

\section{CORRECT ANSWERS IN STUDY GROUP}

There were 60 mothers of neonates in a sample. Each of them has answered 20 questions. Their pre and post-test correct answer were recorded and mean and standard deviation of the test score are obtained as below:

Table 3: Pre test and Post Test knowledge scores

\section{$\mathrm{N}=60$}

\begin{tabular}{|l|l|l|l|l|l|}
\hline Test & Mean & SD & $\begin{array}{l}\text { Paired ‘t' } \\
\text { value }\end{array}$ & DF & $\begin{array}{l}\text { 'p' } \\
\text { value }\end{array}$ \\
$\begin{array}{l}\text { Pre } \\
\text { Test }\end{array}$ & 13.73 & 1.593 & -15.97 & 59 & 0.00 \\
\hline $\begin{array}{l}\text { Post } \\
\text { Test }\end{array}$ & 17.28 & .976 & & & \\
\hline
\end{tabular}


Table 4 Average knowledge Score according to

Education

ONEWAY ANOVA

\begin{tabular}{|l|l|l|l|}
\hline \multicolumn{3}{|c}{ N=60 } \\
\hline Education & N & Mean & St.Deviation \\
\hline Illiterate & 3 & 10.67 & 1.155 \\
Primary Education & 54 & 13.93 & 1.478 \\
Total & 3 & 13.33 & .577 \\
& 60 & 13.73 & 1.593 \\
\hline
\end{tabular}

\begin{tabular}{|c|c|c|c|c|c|}
\hline ANOVA & & & & & \\
\hline Education & $\begin{array}{l}\text { Sum Of } \\
\text { Squares }\end{array}$ & DF & $\begin{array}{l}\text { Mean } \\
\text { Square }\end{array}$ & $\mathrm{F}$ & $\begin{array}{l}\text { "P'" } \\
\text { value }\end{array}$ \\
\hline $\begin{array}{l}\text { Between } \\
\text { Groups } \\
\text { Within } \\
\text { Groups } \\
\text { Total }\end{array}$ & $\begin{array}{l}30.696 \\
119.037 \\
149.733\end{array}$ & $\begin{array}{l}2 \\
57 \\
59\end{array}$ & $\begin{array}{l}15.348 \\
2.088\end{array}$ & 7.349 & .001 \\
\hline
\end{tabular}

Table No- 5 AVERAGE KNOWLEDGE SCORE ACCORDING TO TYPE OF FAMILY

\begin{tabular}{|l|l|l|l|}
\hline Type of Family & N & Mean & $\begin{array}{l}\text { Std. } \\
\text { Deviation }\end{array}$ \\
\hline Joint Family & 45 & 13.91 & 1.571 \\
Nuclear Family & 14 & 13.50 & 1.414 \\
Family & 1 & 10.00 & - \\
Total & 60 & 13.73 & 1.593 \\
\hline
\end{tabular}

\begin{tabular}{|c|c|c|c|c|c|}
\hline \multicolumn{6}{|l|}{ ANOVA } \\
\hline & $\begin{array}{l}\text { Sum of } \\
\text { Squares }\end{array}$ & $\begin{array}{l}\mathrm{D} \\
\mathrm{F}\end{array}$ & $\begin{array}{l}\text { Mean } \\
\text { Squares }\end{array}$ & $\mathrm{F}$ & $\begin{array}{l}\text { 'p' } \\
\text { value }\end{array}$ \\
\hline $\begin{array}{l}\text { Between } \\
\text { Groups } \\
\text { Within } \\
\text { Groups } \\
\text { Total }\end{array}$ & $\begin{array}{l}16.105 \\
133.628 \\
149.733\end{array}$ & $\begin{array}{l}2 \\
57 \\
59\end{array}$ & $\begin{array}{l}8.053 \\
2.344\end{array}$ & 3.435 & .039 \\
\hline
\end{tabular}

\section{CONCLUSION}

The following conclusions were drawn from the following finding of the study.

The health teaching on knowledge of prevention of hypothermia found to be effective in increasing the knowledge of mother. The samples had a highly significant gain in knowledge after the health teaching program.

Age group of 20-30 yrs. showed a gain in knowledge in all the content areas of health teaching.

RECOMMENDATION: Keeping in view the finding of the study, the following recommendations are made:

- A comparative study can be done in hospital mothers regarding prevention of hypothermia.

- An experimental study can be conducted by giving general system model to the mothers, who are attending the hospital as an outpatient on knowledge regarding the prevention of hypothermia in neonates. 
- A study cab be conducted to assess the knowledge practice of mothers regarding prevention of hypothermia in neonates.

- A study cab be conducted to assess the effectiveness of a health teaching on knowledge of mothers regarding prevention of hypothermia.

- A similar study may be conducted by using various methods of teaching like charts, flash cards, flips cards health teaching etc.

- A similar study can be done on a larger sample.

\section{REFERENCES}

01. Abdellah F.G. and Zerine E.Better patient care through nursing research, New York: McMillan Publishing co. 1979, pp- 696.

02. Dorothy R. Marlow, Textbook ofPediatric Nursing, $6^{\text {th }}$ edition, Pp 814815.

03. Ghai O.P., Essential Pediatric, CBS publishers \& Distributors, $6^{\text {th }}$ edition, Pp: - 107,153.

04. Gupta Piyush, Essential Pediatric, $2^{\text {nd }}$ edition, CBS publishers, Pp: -170-173.

05. Meharban Singh, Care of the New Born, $5^{\text {th }}$ edition, Sagar Publication New Delhi Pp: 119,192,196.

06. Parthasarathy A, IAP TEXT book of Pediatric, 3rd edition, Pp: 251-253.
07. Mercer (1995) "hypothermia is not uncommon in full term, low risk newborns. Indian journal of pediatrics volume 31 number 5 pages 298-304.

08. Basvanthappa, “ Nursing theories”, first edition, 2006, jaypee publication new delhi, pp-217-208

09. Oxford \& IBH, New Medical Dictionary; Oxford \& IBH Publishing co.pvt. Ltd., New Delhi Pp; 557,655,998

10. PRATIMA H. MALI The nursing journal of India volume LXXXXI NO. 1 TO8 2000.

11. Braveen Dani (2004)" Effect of planned teaching on the knowledge and practices of nurses in providing oral care to patients on mechanical ventilators" (Unpublishing Master Thesis), Bharti Vidyapeeth college of nursing, pune (2003-2004).

12. S. Jyoti Mary (1991), "infant feeding to primigravidae antenatal and postnatal mothers in terms of their knowledge and practices. PubMed-indexed for Medline.

13. Shersta and Pokharel hypothermia in newborn babies Nursing Journal of India, Vol.xcvi, and Practices of Nursing Research, st Louis, Mosby publication. 